\title{
Environmental Policy in Korea: Conservative Adaptation
}

\author{
LEE, DALGON \\ Associate Professor, Graduate Scbool of Public Administration, Seoul National University
}

\author{
The blue mountains utter no word, \\ the water flows without form, \\ the clear breeze cannot be bought, \\ the shining moon has no owner. \\ Among these I can live free from sickness, \\ I shall grow old without worries
}

Song Hun's Sijo Poem from the address delivered by HRH The prince of Wales, 4th Nov. 1992, Seoul.

\section{The Evolution of the Environmental Policy}

The aim of this paper is to examine the development of environmental policy in Korea and attempt to characterize the policy with comparative perspective.In the first part of this paper, I would like to give a brief history of the Korean environmental policy, then discuss the political economy of each actor's responses to the deteriorating environmental qualities. In addition, I would like to point out several distinctive features which differenciate the Korean environmental policy from those of other countries.

During the last 30 years, more than $50 \%$ of the population moved from the rural areas to the urban areas and more than $75 \%$ of the whole population now live in urban settings. The urban physical infrastructure has not been reinforced according to the urbanization process during the period. In addition to the unprecedented concentration of the population in the urban areas, the rapid industrialization also contributed to degradation of environmental quality. In GDP(Gross Domestic Product) per square kilometer of inhabitable land, Korea ranks just behind Japan: 
Japan ranked twenty times higher than the U.S., six times higher than Britain in the 1960s.

Energy intensive heavy industry had been selected as a base for economic development in the 1970s. Even in the face of energy crisis in 1973, the government as well as the private industry could not have succeeded in changing energy consumption pattern in the heavy industry sector. The government simply swifted policy direction form "oil-primary, coal-secondary" to "maximum utilization of domestic coal."1) Because the government and business were primarily concerned with increasing economic pie, they were not aware of sowing the seeds of tremendous environmental disruption. They were not able to enjoy latitude of mind in preserving environmental values at the time.

But in the late $1970 \mathrm{~s}$, there were several clear evidences that the environmental conditions came seriousely worsening in certain areas, such as, industrial estates, metropolitan areas, nearly urbanizing outskirts, etc. Also, minor local environmental incidences were often reported. No serious policy measures, however, were taken to prevent further deterioration of general environmental quality. Due to the authoritative mature of the government operation at that time, there was no room for conservationists to be able to make themselves, heard by the government decision-makers. In the early 1970s, their were actually few independent conservationists as well as civil movements for environmental protection: all sorts of movements and organizations are dependent on state apparatus, i.e., bureaucracy. Environment-related orgarnizations, if any, were semi-public organization or pro-government in their character.

Factories were scattered all over the country and their pollutants and sewage were not properly treated. The economic policy direction which promoted heavy industry and chemicals basically constituted unfavorable conditions for environmental conservation. Energy consumption has increased very steeply and energy elasticity to GDP has been ever worsening. Although the economy faced difficulties during the first and second oil crises, no effective policy substantive measures were taken to improve energy efficiency and restructure economy. ${ }^{2)}$ In this respects, Japan took a creative policy direction: improvement of energy efficiency through facility investment and development of environment related technologies. The industrial sector also made at most efforts in tackling the task of controlling industrial pollution. They positively shouldered an enormous amount of financial burden on meeting the costs of new investment for pollution abatement equipment. Japan put emphasis on environment-related technology development. Through pierce competition, environmental industry become fired in Japan. By enlarging environmental industry, Japan was able to absorb the potential negative impact of environmental investment on economic performance ${ }^{3)}$.

The Korean government began to recognize the environmental problem as public hygiene issue when the air pollution and water contamination reached serious con- 
ditions in the late 1970's. In the 4th economic development plan (1977-1981), the government added environmental preservation as a new policy goal. But the government still put top priority on economic growth over any other issues. The government initiated enacting several basic environmental laws and establishing organizations to deal with the pollution problem. In the 1980, the government established the Office of Environment through realignment of various regulatory authorities of pollution control. But its position within the governmental decision-making circle was rather weak: the office belonged to the Ministry of Health and Social Affairs and welfare ministries could not exercise their influence over economic ministries. Therefore it was short of integrating necessary authority and resources for effective pollution abatement. The economic-growth-first philosophy in the society had been firmly established. The assumption that environmental protection would harm smooth economic growth was very strongly supported by businessmen as well as policy-makers. The actual function of the Office of Environment had been very much limited for decade thereafter. The phase of then policy development could be called "the phase of ignorant and symbolic policy" or "euphoric enthusiasm": there are policy measures to all appearance but never effectively implemented to attack mounting pollutants. In these stage the public call for solutions and the government and politicians promise action.4)

In the mid 1980's when the environmental condition was deteriorated enough to result in several incidents, several environmental groups became actively involved in mobilizing mass concern. Although these accidents were not serious like Minamata or Itai-itai diseases in Japan, several specific cases in industrial sites showed sufficient evidence that environmental quality became worrisome level. People began to think that the environment, with increased economic living standards must get proper consideration from the government as well as the industry.

Public interest in environmental subjects increased by leaps and bounds. Surveys done in 1982 showed that environmental preservation and pollution abatement ranked 7 th important domestic social problem to be tackled. And its rank went up to the 3rd position in 1987 survey, and ranked the 2nd one in 1990. In the 1991 survey, people tended to think that the environmental quality would deteriorate further domestically and pointed out air pollution (including factory smoke, vehicle sooty smoke, and particles) was the most serious condition followed by water contamination and noise.

Environmental protection which had been instigated through mass media's delivery of the actual state of environmental deteriotarion has caught citizen's deep concern. Scientists warned that the quality is really serious and even laymen can judge the seriousness of the situation through daily interaction with the built environment as well as the natural environment. People tend to give increasing value to the environmental assets. 


\section{The Present Problems and Policy Responses}

Attentive public pointed out importance of prevention and asked for the developers to take the precautionary principle in dealing with natural environment. Economically, it is well known that prevention of environmental degradation is much cheeper than curing environmental damages afterwards. But there is no hints of actual movement toward that direction because nobody is ready to absorb the costs of so called negative negative externality.

As the protest of the citizen groups intensifies, the government began to move in taking further institutional measures. The government increased its budget for abating pollution and asked for the industry to invest more for pollution abatement facilities through upgraded regulation and tight monitory. Environmental regulations were accordingly strengthened as legal framework had been systematically reformed recently. The government began to introduce a partial network of pollution monitoring systems.

The status of the Office of Environment was upgraded to the ministerial level responding to the mounting public demands in 1990. The position of the Ministry has become strongly felt among governmental organizations because environmental issues are connected to almost every aspects of economic activities. Suddenly environmental concern became hot issues which received a fresh impetus from the members of the Economic Vice Ministers' consultation Meeting as well as the Economic Ministers' Consultation Meeting.5)

During 1980s, the government tried to increase the amount of "environmental budget" in the central government level as well as local ones. In 1991, the central government planned to spend $0.16 \%$ of GNP for all kinds of environmental protection activities, But the budget size which is far below the percentage of other advanced countries. The following table shows the share of environmental budget of central governments of several advanced countries in their economy.

Although the above numbers cannot be used as an index of accurate cross country comparison due to the differences of governmental operations and budget system,

〈Table 1〉 GNP Share of Environmental Budget (Central Government only)

(Unit: Percentage of GNP, 1990)

\begin{tabular}{lcccc}
\hline Korea & Japan & U.S. & Sweden & Swiss \\
\hline 0.16 & 0.34 & 0.57 & 1.69 & 1.03 \\
\hline
\end{tabular}

Source: The Ministry of Environment: Environmental White Paper, 1985; and OECD, Environmental Policy and Technical Change, 1985 
the present level of resource allocation for the environmental sector in Korea is funed out to be relatively low. The other advanced countries in the above table had spent much bigger portion of environmental budget in the 1970s when their environment had been most seriously damaged.The present environmental budget ratio of those countries has been relatively low compared to their budget ratio of 1970 s.

For systematic correct comparison of environmental investment, local budgets and private expenditures should be additionally added up to the above figures. Recently, the Korean local governments tend to expand the portion of "environmental budget." But it is not easy to come up with a concrete number because of irregular classification and difficulty of data collection.

But the private business sector is very stingy in investing for pollution abatement. There is regulation game among the government, business, and pro-environmental groups. The industry tries to find every tactic to evade the costs of environmental regulations imposed by the government. The public ask the government to implement regulations more strictly.

The government, which is still strongly biased towards economic efficiency, is hesitating to implement regulations that are often considered as too strict to be accomodated by the industry. But still the government is hesitating in encouraging and subsidizing environmental groups' activities. The present regulation mechanism is basically composed of prohibition and directive using command and control. The Korean government values legislative means, i.e., laws and relies heavily on it as a means of social control. Those inflexible regulation regime should be transformed towards on using economic incentives. Direct regulation system has been proven not so effective in producing the expected results: there may be problems with weak penalty, in efficient administration, or the existing procedures are not streamlined.6) It is clear that all elements of government and industry are not well committed to fighting pollution. Often the effectiveness of government regulation has been criticized. In addition, the court which had played crucial role in strenthening resident's position in Japan, has not played any role in securing responsibilities of the private industry.

The Ministry of Environment is not strong enough to effectively exercise policy tools stipulated in the related law. Especially, the environmental impact assessment system has not been adequately used for environmental preservation. There is few effective ways of forcing the environment impact assessment as a precondition for taking public as well as private projects: The compelling force of the system is limited.

Recently there were several environmental incidents of which scope and seriousness were enough to attract the mass' attention. For example, tons of phenol was leaked from a private electronic factory to the Nakdong River and public water supply was stopped in the South-East areas in March, 1991. After the incident, people began to blame private companies for not having a sense of environmental responsi- 
〈Table 2〉 Portion of Pollution Facility Investment out of Total New Facility Investment in the Private Sector

(Unit: \%)

\begin{tabular}{lccc}
\hline Year & Korea & U.S.A. & Japan \\
\hline 1975 & 0.2 & 5.8 & 17.7 \\
1981 & 0.7 & 2.8 & 4.8 \\
1985 & 0.7 & 2.0 & 4.9 \\
1988 & 0.6 & 1.9 & 4.1 \\
\hline
\end{tabular}

Source: The Industrial Bank(Korea), 1991; Survey of Current Business(U.S.A), 1990; and Ministry of International Trade and Industry (MITI) Documents(Japan), 1990

bility. The incidence accelerated public's distrust in quality of drinking water which had been deteriorating for a long time. Several big companies pretend and even promised to pay attention to their environmental responsibilities. Still there are no such proofs that they are really committed to invest an appropriate money on emission control equipment. They simply established independent organizations for environmental protection. But its activity is very limited.

The following table shows how much money is used in buying pollution abatement facilities out of total new facility investment in the private sector.

As can be seen from the above table, the present level of investment for pollution abatement by the industry in Korea is far below than the figures of the other two countries. While the other two countries spent much higher portion of their facility investment for pollution abatement during the 1970s, ${ }^{7}$ ) the figures of Korea are not increasing recently in spite of deteriorating quality of her environment. It is well known fact that $17.7 \%$ of new facility investment was used for purchasing pollution abatement equipment in Japan in 1975. The record breaking investment resulted in very positive economic performance rather than commonly believed negative impacts on macro economic indicators. ${ }^{8)}$

The total amount of money used in pollution abatement activities in Korea, including government budget and private investment all together, seems to recently reach around $0.7-0.8 \%$ of her annual GNP.9) Advanced countries with moderately sound environment quality had usually spent about $2 \%$ of their annual GNP for environmental protection during $1970 \mathrm{~s}$. According to an estimate by the OECD, the ratio of Japan's expenditure for pollution control measures to the gross domestic product (GDP) reached 3 percent in 1975. This level for surpassed the corresponding ratios of pollution control expenditures in other industrialized countries. ${ }^{10}$ ) And the U.S. has plan to increase environmental expenditure up to $3 \%$ of her annual GNP in the next 10 years. ${ }^{11)}$

The government, recently, established a comprehensive 5 year environmental 
〈Table 3〉 Investments Scheduled in the 5 Year Comprehensive Environmental Plan

(Unit: Trillion Won $=\$ 1 / 800 ;$ \%)

\begin{tabular}{lcccccc}
\hline & Total Invest. & 1992 & 1993 & 1994 & 1995 & 1996 \\
\hline GNP estimated (A) & & 226 & 257 & 288 & 321 & 357 \\
Total (B) & 12.2 & 2.4 & 2.8 & 2.8 & 2.6 & 1.6 \\
B/A (\%) & & $(1.07)$ & $(1.24)$ & $(1.00)$ & $(0.74)$ & $(0.44)$ \\
Public Sector & 6.7 & 0.9 & 1.4 & 1.5 & 1.6 & 1.3 \\
Private Sector & 5.5 & 1.5 & 1.4 & 1.3 & 1.0 & 0.3 \\
\hline
\end{tabular}

Source: The Ministry of Environment, Environmental White Paper, 1991

upgrading plan (1992-1996). In the plan, environmental quality improvement program is still recognized as a subset of economic development plan. In the government decision-making circle, policy-maker's their mental map cannot overcome the growth-first-orientation. Although "harmony between environmental preservation and healthy development of the economy" had been mentioned as a policy goal from the 4th economic-social development plan(1977) down to this day, the balance was not actually realized. The plan carries many projects which will need a huge investment from the public sector as well as the private sector. The above table shows its investment plan.

When we compare the GNP ratio of the present environmental investment, i.e., 0. 7\% of GNP,with those goals (1.24-0.44\%) set in the plan, it is really an ambitious scheme. But the plan did not mention any specific schemes to timely mobilize the required financial resources. Many commentators are doubtful about the feasibility of realizing the dream of the Ministry of Environment. It is, also, not clear whether appropriate cnvironmental quality will be maintained after 1995: Investment is supposed to drop sharply after the year and the burden shared by the private sector is shrinking very rapidly.

The role of the private industry should be emphasized even after 1995 in cleaning up the accumulated pollutants and maintaining adequate level of environment which gocs along with advanced material living standard and changed concern with better environment. It may take several years to move capital investments. But adequate level of operating and maintenance expenditure should be continued to maintain the improved quality there after. Out of several policy measures taken by the government recently, it must be emphasized that she puts much efforts on developing environmental technologies, i.e., clean technology. The government formulated G7 Project that aimed to enhance the Korean technological capacity to the level of advanced countries. In the grand plan, clean technology was chosen as an area of national priority in research and development. And bio-technology is another area of policy priority. 
With this grand policy, human and material resources will be devoted to this area with much emphasis than before. But the decision maker's orientation is still clinging to economic efficiency. It is really hard to find any clue that policy-makers tend to think the environmental sector as equivalent to the economic sector. Consistently, they think that the environmental issues should be dealt within the framework of economic efficiency. In this sense, the government and the industry are not ready to realize the acceptive, sustainable development, not to mention the environmentally sound and sustainable development(ESSD).

The pressure from domestic environmental movement and international environmental regulations, however, puts the government to move towards a bit positive position for environmental protection. The government boisteriously collects policy ideas and sponsors seminars and conferences on environmental protection, but the decision-makers within the government confess that those noisy activities are carried out to protect industry and economy from international pressures. They move too slowly because they are comfortable about the potential negative impacts of environmental protection on the economy.

\section{Upgrading Policy Process}

During recent years, there has been a sudden upsurge in verbal emphasis on the importance of public participation in government decision making as well as implementation of environmental policies. During the 6th Republic, the government authorities, with where the President siting on the first on a list in a roll, emphasizes the democratization of domestic political process. Although the bureaucracy stands in the way of democratization, the general context of government operation has been changing. ${ }^{12}$ )

The Public ask the government to release detailed informations regarding the present situation of the environmental quality. Also people ask the government to advocate participatory decision-making in setting regulations and investigating environmental incidents. Potential victim of environmental incidents, they argue, should be presented when the government deals with environmental protection measures in certain districts.

Public officials began to realize the effectiveness of citizen participation in attacking environmental problems. Activities of NGO(Non Governmental Organization) should be encouraged and the government should find way to help their activities through information sharing as well as financial aids. The emergence of intermediary groups in the Korean politics is another phenomenon indicative of growing mass confidence in the citizen role.Environmental group and increased concern of mass media are indicative of new pattern of political participation that contradict the traditional characterization of Koreans as politically passive, indirect participation 
through limited voting or formal contact with the state bureaucracy.13) Whereas the role of the courts had been crucial in solving environmental problems in Japan, there is no such activism in the Korean courts yet. Environmental movement can be encouraged if the court pay proper attention to the aggrevated environmental problems. ${ }^{14)}$

Nowadays the mass media mobilizes citizen participation in reducing solid wastes and the government now realizes the importance of public-private partnership in solving environmental problems. There are serious local oppositions against the government's designation of landfill or disposal sites. Mass petition and demonstration against proposed physical projects has been a everyday occurrence. So called NIMBYs(Not In My Backyard Syndrom) has suddenly hit the Korean society. The era of PIMFY(Please In My Front Yard) seems to have gone forever in Korea. Because financial resources needed in compensating damages done on the private property is limited, it is not easy to resolve the conflict among citizen, the government, and developer. It is well known that adequate compensation with well designed participating decision-making process in the key variable for cooperative resolution of policy conflict. 15) Also, local residents have experienced the rewards of their fierce request activities from the government. They feel the efficacy of their demonstration.

Realizing the importance of the citizen's movement in this field, the central government tries to delegate its functions to the local government which are burgeoning out recently. Almost all the key decisions regardless of their regional boundary have been decided by the central government in 1980s. And the central government has been the target of public distrust and criticism. Decentralization will definitely encourage citizen's participation in handling the public problems in the long run.

Organizationally the environmental policies are formulated and implemented through four level of bureaucratic tiers: the central government (The Ministry of Environment), the 6 Regional Environmental Agencies which are arms of the Ministry, the 15 secondary local governments, and the 258 primary local governments. The central ministry has 6 regional offices which the Japanses government does not have. Recently, some function of the 6 Regional Office are transformed to the secondary as well as primary local governments. Although regional and national measures are still important, it is further more emphasized that the local governments, which are closer to everyday lives of local residents, assume priority role in attacking environmental deterioration and prescrving natural environment.

The national assembly has not been so active, but the local councils have begun to take some role in preserving local environment. The council often instigates regional egoism, raising environmental conflict in order to protect local interest. But their basic orientation is pro-business. Political parties began to take environmental protection as a plank of party platform. But it is very hard to judge which party is more pro-ecology. The Korea Green Party which was founded a couple of years ago did 
not try to sponsor a political candidate for legislative seat. They simply regard themselves as social activists. The party does not draw enough public attention to be able to exert a great pressure on the ruling system like in Germany and Japan.16) In sum, the public decision-making bodies passively adapt environmental policy direction to the change of environmental quality without clear policy direction nor vision. The situation is really transitional with minor policy change when compared to the fast deteriorating environments.

\section{Promoting Partnership and Cooperation}

Nowadays environmental issues are not restricted to a district or a country. It is a matter of life or death of all mankind. Environmental deterioration, with war, poverty, and narcotic, composes the 4 human evils in the industrialized era. Also the problem itself is not so simple to be tackled with a single policy measure. Environmental issues include technological, economical, attitudinal, cultural and political aspects. And the priority of upgrading and preserving environment should be consolidated as global industrialization proceeds.

However there have been serious cleavages between government and NGOs, developer and environmentalist, business and ordinary citizen, advanced countries and developing countries (North-South conflict), to mention a few. Even within the government there has been a clear cut cleavage between economic bureaucrats and welfare bureaucrats regarding the priority of resource allocation for environmental soundness. Everybody wants to enjoy sound environmental goods but is afraid of sharing burden.

The Korean government, however, attempts to institutionalize an integrated environmental management system which attempts to ensure cooperations among related parties and asks shared responsibility in upgrading environmental qualities and preserving natural environment. The government realizes the importance of incentive system which will make rewards to the actors who contributed to reducing the negative environmental externalities. The government should encourage formulation of NGOs their activities, asking the industry to take their due responsibility. But still the government is hesitating in encouraging and subsidizing environmental groups or movements. The present regulation mechanism is basically composed of prohibition and directive using command and control. Those inflexible regulation regime should be transformed towards one wing economic incentives.

In addition to the domestic partnership policies mentioned above, the government tries to extend its arms to the neighboring countries as well as to the global friends. As proposed by the Korean Prime Minister in the Rio conference last June, the government assumes leadership in establishing "North-East Asian Environment Conference" in the near future. The Ministry of Foreign Affairs, in cooperation with 
the Ministry of Environment, plans to assume an active role in global environment negotiations. Because Korea is sandwiched between the advanced countries and underdeveloped countries, she can take the role of mediator, compromising the conflicting interests.

The conference, if any, will include North and South Koreas, China, Japan, CIS, and Mongolia. Those countries include $27.9 \%$ of world population and their territories cover $21.2 \%$ global land surface. Although the interests of each country at stake is different, the pie of joint gain which will be realized in the near future and will increase rapidly. The government expects indirect help from the OECD, UNDP, and UNEP. The region emits 25 million tons of $\mathrm{SO}_{2}$ which is equivalent to the emission poured out all Europe in 1972; 20 million tons of $\mathrm{SO}_{2}$ which is $15 \%$ of world total. If the conference find ways to reduce the emmisions without seriousely harming economic development, then it contributes to upgrading the global air stability significantly.

\section{Notes}

1) Lee, Dalgon, "Backward Mapping Analysis of an Urban Energy Policy," Unpublished Ph.D. Dissertation, Harvard Univ., 1987, pp.248-264.

2) Lee, Sang-Gon, "Development Strategy and the Environmental Policies," Environmental Economic Review, Vol. 1, No. 1(Spring, 1992, Seoul), pp.228-229.

3) Heidenheiner, Arnold J., Hugh Heclo and Corolyn Teich Adams, Comparative Public poli$c y$ (New York: St. Martin's Press, 1990), pp.337-340.

4) Downs, Anthony, "Up and Down with Ecology the Issue Attention Cycle," Public Interest No. 28(1972), pp.38-50.

5) Both Meetings actually coordinate the Korean economic policies among related government organizations.

6) Anderson, Frederick K. and et al., Environmental Improvement througb Economic Incentives (Washington D.C.: Resources for the Future, Inc., 1977), pp.145-191.

7) OECD, Macro-Economic Evaluation of Environment Programs (Paris: OECD), 1978, pp. 27-63.

8) OECD, The Macru-Economic Impact of Environment Expenditure (Paris: OECD), 1985.

9) Rhee, Jeong-Jeon \& E.S. Shin, Policy Instruments for Environmental Improvement, (Seoul; International Trade and Business Institute, (Korea) 1991.)

10) Environment Agency, Government of Japan, Twenty-Year History of the Environmental Agency (summary), 1991, p.4.

11) Habicht II, F. Henry, "Asian-American Partnership for a Better Global Environment," Current Views, No.3. (1992), pp.60-64.

12) Kim, Bun Wong, "Democratization and Administrative Reform in Korea: A New Direction," in Caiden, Gerald E. and Kim, Bun Wong (eds.), A Dragon's Progress (West Hartford, Conn.: Kumasian Press, 1991), pp.246-249.

13) Henderson, Gregory, Korea: The Politics of the Vortex, (Cambridge, M.A.: Harvard 


\section{The Korean Journal of Policy Studies}

University Press, 1978), pp.365-376.

14) Pempel, T.J., Policy \& politics in Japan (Philadelphia; Temple University Press, 1982), p. 229.

15) Rabe, Bang G., "Beyond the NIMBY Syndrome in Hazardous Waste Facility Siting," Governance, Vol. 4, No.2(April 1991), pp.184-206.

16) Weidner, Holmut, "The Capability of the Capitalist State to Solve Environmental Problems: the Examples of Germany and Japan," a paper presented at the XVth World Congress of the International Political Science Association, Buenos Aires (July, 1991), pp.17-21. 